This is a Rewieved Article

\title{
Toleranse, kultursensitivitet og akkulturasjon: Interkulturelle utfordringer for primærhelsetjenesten og nyankomne innvandrere i Norge
}

\section{Keywords:}

akkulturasjon

innvandrer

kultursensitivitet

likeverdige helsetjenester Norge

primærhelsetjenesten

toleranse acculturation

immigrant

cultural sensitivity

equitable health care services

Norway

primary health care

tolerance 


\begin{abstract}
Background: Since the 1970s, Norway has experienced a significant increase in population diversity. In 2001, a patient-list system, also referred to as the General Practitioner (GP) Scheme (Norwegian: Fastlegeordning), was introduced to ensure access to primary health care for the entire population. At the time of its introduction, the scheme, which was designed for a homogenous population, was intended to improve the quality of GP services. By facilitating stability and continuity in the doctor-patient relationship, the scheme aimed to ensure equitable access to, and use of, secondary health care. Despite the intention to facilitate stable doctor-patient relationships, employees in health care facilities report that many immigrants use the emergency room rather than GP services. Equity in health care is the absence of systematic disparities in health care. Since the provision of equitable health services is a priority in Norway, this study aimed to investigate the possible motives for immigrants' choice of service provider and to propose measures to increase the uptake of GP services by this group.
\end{abstract}

Purpose and approach: The aim of the article is to examine newly arrived immigrants experiences with primary health care. The article attempts to shed light on why immigrants seek medical help at the emergency room and not from their assigned GPs in non-lifethreatening situations.

Methods and materials: We adopted an exploratory approach in order to investigate both the motives and experiences of diverse groups of immigrants. Semi-structured interviews were conducted with 12 Oslo GPs and 13 immigrant representatives, all living in Oslo. To illustrate patterns on a large scale, we adopted a quantitative approach based on data from health authorities' registers of consultations. 1,935,000 primary health care consultations conducted in the Greater Oslo area over a two-year period were included in the regression analyses.

Results and interpretation: The study shows a varied pattern of use of GP services among the diverse groups of foreign-born residents. Results suggest that immigrants are more likely to use emergency-room services during the first few years after arrival. Results also indicate that information about the patient-list system does not always reach newly arrived immigrants. Contrary to general understanding, non-visible immigrants (when considering factors such as skin color and clothing) diverge the most from the pattern of the majority. Immigrants originating from European countries, such as Sweden and Poland, use the emergency room most frequently. From the qualitative aspects of the study, we have also found that primary health care services are not perceived as equitable.

Conclusion: Recently arrived immigrants' utilization of primary health care services shows an unfavorable pattern. The choice of primary health care service providers is dependent on the individual's preferences, expectations, experiences and/or actual obstacles. The observed utilization of services provided at emergency rooms is one more reason for monitoring and increasing tolerance and cultural sensitivity in primary health care. 


\section{Innledning}

Artikkelens formål er å belyse innvandreres tilgang til primærhelsetjenesten (legevakt og fastlege), samt se på muligheter for å begrense uønskede hendelser og mønstre innen primærhelsetjenesten. I Norge er det et helsepolitisk mål å legge til rette for likeverdige helsetjenester. Denne studien ser derfor også på mulige årsaker til at innvandrere ofte også i ikke-akutte situasjoner oppsøker legevakten fremfor fastlegen, og hvordan bruk av fastlege kan fremmes hos innvandrergruppene.

Siden midten av 1970-tallet har innvandring og globalisering i økende grad gjort Norge til et flerkulturelt, fleretnisk, og flerreligiøst samfunn. Nettoinnvandringen de siste årene har blitt større og involverer nye land (Vassenden, 2012). I 2013 bodde 539.000 innvandrere fra 220 ulike land og selvstyrte regioner i Norge. Innvandrerne utgjør $12 \%$ av den norske befolkningen (Statistisk sentralbyrå, 2013) og finnes i alle norske kommuner. Med 30,4\% (ibid) har Oslo den desidert største andelen av den delen av befolkningen som defineres som innvandrere samt av deres etterkommere. Innvandrere er i denne sammenhengen definert som personer født i utlandet og som senere har flyttet til Norge. Deres etterkommere som er født i Norge, er følgelig ikke innvandrere, og omfattes heller ikke av begrepet innvandrere i denne artikkelen.

I dag fremstår Norge med en langt mer heterogen befolkning enn for bare en generasjon siden. Denne heterogene utviklingen har også konsekvenser for helsevesenet.

I den nasjonale helseplanen for 2007-2010 står likeverdige helsetjenester oppført som et sentralt mål (Helse- og omsorgsdepartementet, 2006). Likeverdige helsetjenester forutsetter likhet i tilgang, kvalitet og resultat ved at helsevesenet legger til rette for at den enkelte pasient skal ha likeverdig tilgang til omsorg og behandling. Helseplanen viser til at det er betydelige forskjeller i befolkningens helse langs etniske variabler, noe som her korrelerer med ulike mønstre som kommer til syne gjennom bruken av helsetjenestene.

Som påpekt gjennom nasjonale føringer de siste 10-15 år er likeverdige helsetjenester og tilgjengelighet avgjørende for å kunne redusere sosiale ulikheter innen helse. Dette bekreftes av tidligere forskning, som også viser at holdninger er et komplekst fenomen med stor variasjon mellom de ulike gruppene av innvandrere (Klüwer-Trotter og Lian, 2012). Mangfoldstanken impliserer at tjenestene må utformes i respekt for pasientenes integritet og verdier. Selv om kulturforskjellene mellom gruppene kan oppleves som store, så avtar disse over tid for de fleste gruppene (Kymlikcka, 1995). Innvandrerne og deres etterkommere befinner seg $i$ en minoritetssituasjon som preges av transnasjonal identitet, og hvor det forventes at gruppen tilpasser seg majoriteten i samfunnet.

Migrasjon medfører i seg selv en helserisiko (Dyhr og Krasnik, 2006). Hvor stor denne risikoen er, avhenger av årsaken til migrasjonen, omstendighetene rundt migrasjonen, egne forventninger og hvilke tap migranten har opplevd i denne prosessen. I mottakerlandet Norge møter migranten en rekke krav, og mye nytt må læres. Immigrasjon medfører også utfordringer for etablerte systemer i destinasjonslandet, og helsetjenestene må tilrettelegges dersom likeverdigheten skal ivaretas. Stortingsmelding 10 "God kvalitet trygge tjenester 2012-2013" har som målsetning å tilby likeverdige helsetjenester. Dette gjør det nødvendig å utforme tjenestene slik at hensynet til minoritetene blir ivaretatt, og at det blir tilrettelagt for dette $\mathrm{i}$ de individuelle konsultasjonene. For å kunne tilrettelegge individuelle konsultasjoner belyste Klüwer-Trotter og Lian nordmenns adferd ved bruk av helsetjenester (2012). Deres undersøkelse fokuserte på utdanning, og det kom frem at ulike språkferdigheter og kunnskap om helsesystemet medførte ulik adferd i møte med primærhelsetjenesten. 
Fastlegeordningen, som ble innført i 2001, tar sikte på å forbedre kvaliteten på tjenestene til allmennlegene i primærhelsetjenesten (Godager og Iversen, 2010). Tidligere forskning i Norge har vist at legevakten brukes av befolkningen til mer enn øyeblikkelig og nødvendig helsehjelp, men at fastlegen foretrekkes av befolkningen dersom tilgjengeligheten er god (Halvorsen, Meland og Bærheim, 2007; Godager og Iversen, 2010). Fastlegeordningen forutsetter at alle innvandrergrupper og nasjonale minoriteter forholder seg til denne ordningen på samme måte som majoritetsgruppen i samfunnet. En forutsetning for å kunne etablere likeverdige helsetjenester for alle grupper er at disse tjenestene i seg selv er adaptive. Dersom et helsetilbud utformes på bakgrunn av kulturen og behovene hos majoritetsgruppen, vil tilgjengeligheten for individer fra andre grupper henge sammen med graden av integrering, assimilering og eksisterende separasjons- og marginaliseringsstrategier. Hvor mye stress eller tilpasning den enkelte vil oppleve er individuelt (Berry, 1997/1989).

\section{Begrepsavklaringer:}

Et viktig aspekt ved migrasjonsforskning er akkulturasjon (Bøhn, 2008), som forstås som et fenomen som inkluderer både kulturelle og psykologiske aspekter (Berry, 1997). Akkulturasjon slik begrepet brukes $\mathrm{i}$ artikkelen, beskriver de endringene en innvandrer gjennomgår ved flytting fra en kultur til en annen, og som her omfatter alle forandringene som oppstår når individer og grupper med forskjellig kulturbakgrunn kommer i kontakt med hverandre (Berry 1997, Berry et al., 2011).

Fenomenet beskriver virkningen av at grupper fra ulike kulturer har førstehåndskontakt med hverandre, noe som fører til endringer i det opprinnelige kulturelle mønsteret i en eller begge gruppene (Redfield, Linton og Herskovits, 1936:419, min overs.). Akkulturasjon er i utgangspunktet et nøytralt begrep, som går ut fra at endringen foregår både $i$ den dominante kulturen og i minoritetskulturen. Dersom grupper av svært ulike størrelser kommer i jevnlig kontakt med hverandre vil en som regel finne de største endringene hos den minste gruppen (Berry, 1992). Dette beskriver endringer på gruppenivå, men også på individnivå skjer omfattende prosesser hvor interkulturell kontakt skaper endringer $\mathrm{i}$ individet selv, både affektive, kognitive og atferdsmessige endringer (Berry, 1997). Under akkulturasjon vil gruppene og deres individuelle medlemmer engasjere seg i interkulturell kontakt, og det er her potensielle konflikter kan oppstå. Slik interkulturell kontakt kan finne sted i helt dagligdagse situasjoner, som for eksempel under et legebesøk.

Toleranse som et normativt og deskriptivt begrep beskriver evnen til å leve med andres meninger, holdninger og/eller handlinger, også når man selv ikke slutter seg til disse. I denne artikkelen forstås toleransebegrepet slik at det også omfatter retten til à ha divergerende oppfatninger og forestillinger. Norske data viser en positiv sammenheng mellom utdanningsnivået og toleranse for innvandrere og innvandring (Blom, 2010). Her viser det seg at skillelinjen ligger mellom utdanning på videregående nivå og utdanning på høgskole eller universitetet (ibid:4).

Kultursensitivitet slik Magelssen definerer det er ikke knyttet til et spesifikt kulturbegrep, men skal hjelpe frem en mer symmetrisk maktrelasjon og gi bedre rom for gjensidig respekt når mennesker med ulik kulturell bakgrunn møtes (2008:142).

Det kan oppleves som utfordrende å etablere seg og integreres $i$ et nytt land med ukjent språk, fremmed klima, komplekse offentlige systemer og en fremmed kultur med andre rolleforventninger. Derfor vil den enkelte innvandrer som har andre kulturelle forutsetninger, være avhengig av at medarbeidernes kompetanse til å kommunisere på en hensiktsmessig og passende måte $i$ en gitt situasjon (Dahl, 2001, s.175). Våre ytringer og 
handlinger fremstår som meningsfulle for andre i den grad disse andre deler det samme meningsuniverset, eller meningsfellesskapet. Da vil de kunne tolke våre ytringer og handlinger i sin rette sammenheng.

Kultursensitivitet er evnen til å forstå at ytringer og handlinger som ikke umiddelbart fremstår som forståelige like fullt kan være både meningsfulle og logiske i lys av andre kulturelle meningsunivers enn ens eget. Meningsunivers brukes her som en samlebetegnelse for de ideer, normer og verdier som er felles for en gruppe mennesker. Vi tolker og gir mening til omgivelser og hendelser i lys av slike meningsunivers, og også våre egne ytringer og handlinger refererer til vårt eget meningsunivers (ibid).

Som prosess vil en kultursensitiv tilnærming både skape og forutsette en toleranse forankret på individnivå. Akkulturasjon, en prosess som her beskrives ut fra minoriteten, når man forholder seg utenfra ens egen kultur (Berry, 2011). Ved kontakt mellom grupper med forskjellige kulturelle erfaringsunivers, vil en kultursensitiv tilnærming kunne muliggjøre kommunikasjon og bidra til å etablere en ny og felles situasjonsforståelse. Kulturoverføring $\mathrm{i}$ en akkulturasjonsprosess forutsetter en langvarig kontakt mellom individene (Skirbekk,1975).

\section{Materiale og metoder}

\section{Aktørperspektivet:}

For å kunne forstå tanker om helse og handlemåter er det nødvendig å sette seg inn i innvandrernes situasjon og kulturelle meningsunivers. Ved å anvende et aktørperspektiv tilstreber man å se situasjonene fra aktørens ståsted, og gjennom dette oppnå et "innenfraperspektiv" der ytringer og handlinger forstås som meningsfulle i lys av aktørenes egne forståelsesrammer (Johnsen 1986:62). Aktørperspektivet søker å forstå på egne premisser, men impliserer ikke at man også må godta den andres perspektiv og praksiser. Metoden må heller ikke forlede en til å skape en konstruksjon eller forestilling om den "eksotiske" andre, og derved overdrive den andres forskjellighet (Ihle, 2008:50). Aktørperspektivet skal være en metode til å belyse konsekvenser og handlingsmønstre som skyldes divergerende forståelsesrammer.

Metoden som ble brukt til å belyse problemstillingen er derfor basert både på en kvalitativ del og en kvantitativ del som blir samanalysert ved hjelp av Mixed Methods (Teddlie og Tashakkori, 2009). Den kvantitative delen ble utviklet på grunnlag av funn fra analysene i den kvalitative delen.

\section{Kvalitativ metode}

En viktig tilnærming i den kvalitative delen var å kartlegge innvandreres bruksmønster i primærhelsetjenesten (fastlege og legevakt). For å finne mulige årsaker til bruksmønsteret ble det benyttet informanter som kunne formidle henholdsvis innvandrernes og fastlegenes erfaringer og holdninger. Dette ble etterfulgt av et systematisk litteratursøk (Goth, 2012:47-54). De kvalitative dataene er basert på semistrukturerte intervjuer med tolv fastleger i Oslo-området, tretten nøkkelinformanter fra organisasjonene til de største innvandrergruppene i Norge, samt dybdeintervju med ledende ansatte ved legevakten og flyktninghelsetjenesten. Tretten nøkkelinformanter fra innvandrermiljøene fungerte som kulturoversettere og formidlet innvandrernes ståsted. Informantene ble valgt ut fra en liste etter anbefaling fra Innvandrerrådet i Oslo. Alle informantene har innvandret til Norge og hadde ledende funksjon i en innvandrerorganisasjon. Tolv fastleger med virke i Oslo ble inkludert i studien for å belyse legenes opplevelse av innvandrerne i primærhelsetjenesten. 
Alle leger ble inkludert etter "snowball" metoden (Patton, 2002). I tillegg ble én ansatt ved legevakten og én ved flyktningehelsetjenesten intervjuet.

Alle intervjuene ble gjennomført ved hjelp av semi-strukturerte spørreskjema, som belyste tilgjengeligheten av fastlegeordningen. Den analytiske tilnærmingen var basert på "grounded theory» (Glaser and Strauss, 1967). Dataene som ble innhentet ble klassifisert, kategorisert og analysert av to forskere og verifisert med funn fra litteraturstudien. Resultater som blant annet bolengde, fødeland og kjønn fra de kvalitative analysene dannet utgangspunkt for valg av de uavhengige variablene som ble inkludert i regresjonsmodellen. Kvalitative resultater som beskrev mulige årsakssammenhenger ble deretter brukt for å belyse de kvantitative resultatene som var basert på registerdataene.

\section{Kvantitativ metode}

Data i den kvantitative delen var basert på registerdata fra Konsultasjonsregisteret til Arbeids- og velferdsforvaltningen (NAV). Data fra konsultasjonsregisteret ble av Statistisk sentralbyrå (SSB) koblet med demografiske data fra Folkeregisteret. Alle variabler $\mathrm{i}$ analysen ble brukt slik SSB definerte dem i perioden da data ble utlevert (2003-2008) (Statistisk sentralbyrå, metadata).

Da helsetjenestetilbudet i Norge kan variere mye fra sted til sted (Godager og Iversen, 2010), ble bare persondata fra Oslo inkludert i analysen for å sikre at dataene deler samme kontekst i form av enhetlige rammevilkår. Analysene inkluderte alle primærhelsekontakter (fastlege og legevakt) for årene 2006 og 2007 for innbyggere bostedsregistrerte i Oslo. Datasettet for Oslo består av ca. to millioner konsultasjoner (registreringer).

Det gjennomsnittlige antall primærlegebesøk per år ble beregnet på grunnlag av registrerte konsultasjoner hos primærleger og legevakt som blir innsendt ved oppgjør og deretter registrert i konsultasjonsdatabasen ved Helseøkonomiforvaltningen (HELFO). Andel legevaktkonsultasjoner ble beskrevet i prosent på bakgrunn av primærlegekonsultasjonene som hadde foregått på legevakt. Variablene som ble identifisert gjennom analysen av intervjuene med fastleger og nøkkelinformanter ble bekreftet av litteraturen (Berry, 1989; Berry, 1992). De avhengige variabler i regresjons-analysene som ble gjort i STATA 11 var alder, kjønn, fødeland og botid i Norge.

\section{Etikk}

Innhenting av data og analysen ble gjennomført i henhold til Helsinki-deklarasjonen og personopplysningsloven. Alle kvalitative data som ble innhentet ble anonymisert i etterkant. Kvantitative data som ble utlevert fra dataeier ble koblet ved SSB og distribuert i anonymisert form. Regional etisk komité (REK nr.: 437-08437c; 2008/10427; 2010/537) og personvernombudet for Oslo Universitetssykehus (2008:1206) og Helsedepartementet (200902387/VAS) har godkjent utlevering av både data og studien i sin helhet.

\section{Styrker og svakheter}

Styrken ved denne undersøkelsen er at den bygger på et komplett register over så godt som alle primærlegekonsultasjoner i Oslo i 2006 og 2007. Resultatene fra den kvalitative analysen dannet utgangspunkt for valg uavhengige variabler som ble inkludert i regresjonsmodellen, og de ble også benyttet ved tolkingen av de kvantitative resultatene.

Den primære svakheten i den kvantitative modellen er at bare personer som har brukt primærlegetjenester i 2006 og 2007 er inkludert i datamaterialet. Vi kan derfor ikke 
beregne bruken av primærlegetjenester i hele innvandrerbefolkningen. Videre er variabelen etnisitet problematisk, fordi "fødeland" er en grov gruppering som ikke nødvendigvis er sammenfallende med etnisk tilhørighet. Samfunn kan ha store minoritetsgrupper, og som et eksempel vil kurdiske flyktninger i statistikken fremstå bl. a som tyrkere, iranere eller irakere.

Den kvalitative studien har et lavt antall informanter. Under datainnsamlingen valgte vi å avstå fra å bruke audiovisuelle hjelpemidler, og informasjon ble i stedet nedskrevet under intervjuene. Årsaken til dette var ønsket om ikke å begrense mottakelsen av sensitive data - noe en kan risikere ved bruk av audiovisuelle hjelpemidler.

\section{Resultater}

Avsnittet deles inn i presentasjon av kvalitative og deretter av de kvantitative funn.

\section{Kvalitative resultater}

Kategoriene som kom frem i analysen av intervjuene med innvandrerrepresentanter og fastleger var: a) avklarte rolleforventninger, b) sosiokulturelle ulikheter, c) mangel på informasjon mellom legevakt og fastlege, d) mangel på systemkompetanse og e) kommunikasjonsproblemer mellom lege og pasient.

a) Rolleforventning:

"Fastlegene spør pasientene hva han (legen) skal gjøre! Det skjønner ikke pasienten (innvandreren). Det er jo derfor (for å få råd) han (pasienten) kommer til legen."

\section{Innvandrerrepresentant fra Bosnia.}

Resultater indikerer at det var divergerende rolleforventninger mellom innvandrere og legen. Dette inkluderer at rolleforventningene hos innvandrere kan divergere fra majoritetsbefolkningen. Mens fastlegeordningen tar felles rolleforventninger for gitt, kan kunnskapen om selve fastlegeordningen (systemkompetansen) være mangelfull. Systemkompetansen omfatter kunnskap om legens ansvarsområde og om hvordan det forventes at en opptrer under interaksjonen. Under de kvalitative intervjuene eksemplifiserte både fastlegene og innvandrerrepresentantene hvordan uavklarte forventninger kan skape utfordringer i møte mellom helsetjenestene og innvandrerpasientene. Det er disse uavklarte forventningene som i stor grad er årsaken til legenes økte tidsbruk, misnøye og frustrasjon. Funn relatert til uavklarte forventninger kunne knyttes til fødeland. Innvandrerrepresentanter fra Polen og Sverige gav uttrykk for at "arbeidsinnvandreren" foretrekker å besøke fastlegen hjemme,

b) Sosiokulturelle ulikheter:

«innvandrerpasienter er dem som kommer fra områder utenfor Europa, Nord-Amerika og Australia, og som snakker hverken norsk eller engelsk"

\section{Mannlig norsk fastlege.}

I intervjuene med fastlegene ble det tydelig at "innvandrere" ble definert med utgangspunkt i opplevde sosiokulturelle ulikheter. Usikkerhet i selve interaksjonsmønsteret basert på språkkunnskaper ble nevnt, spesielt når resultatene viste at tilgjengelig informasjon om det norske helsesystemet ikke nådde frem (Goth 2010). Familie, venner, innvandrerorganisasjoner, arbeidskolleger og religiøse felleskap ble nevnt som hovedkilder for 
informasjon. Det andre aspektet som ble nevnt, er i hvilken grad innvandrergruppen har et annet lidelsesspektrum enn befolkningen for øvrig.

c) Mangel på informasjon mellom legevakt og fastlege

"Det oppfattes som vanskelig at ikke alle legevakter sender informasjon til pasientens fastlege (etter besøk ved legevakten)"

Mannlig fastlege født utenfor Norge.

Ikke alle legevakter sendte epikrise (rapport fra konsultasjonen) til den registrerte fastlegen etter en konsultasjon - noe som er en forutsetning dersom fastlegen skal kunne følge opp pasienten.

d) Systemkompetanse:

«Det er ingen som forstår informasjonsskrivet som kommer i posten, det er så vanskelig å lese»

\section{Innvandrerrepresentant fra Somalia.}

Både fastleger og innvandrerrepresentanter påpekte at innvandrerne mangler kunnskap om oppbygningen av primærhelsetjenesten og fastlegeordningen, og dermed også kunnskapen om at en kan skifte fastlege. Intervjuene med både innvandrerrepresentantene og fastlegene viser at nyankomne innvandrere generelt har lite kjennskap til helsesystemets oppbygging, omfanget og rammevilkårene til fastlegeordningen.

Det viste seg videre at et introduksjonsbrev med informasjon på norsk om fastlegeordningen sendes ut (HELFO) seks uker etter at innvandreren har søkt om botillatelse $\mathrm{i}$ forbindelse med familiegjenforening, utdanningsinnvandring eller arbeidsinnvandring. Det viste seg at introduksjonsbrevet ofte ikke kommer frem fordi den nyankomne innvandreren i mellomtiden har flyttet fra en midlertidig til en mer permanent adresse. Dersom brevene kommer frem blir de som regel ikke forstătt fordi mottaker (etter 6 uker) ennå ikke behersker norsk.

e) Kommunikasjonsproblemer mellom lege og pasient:

«Ikke alle fastleger bruker tolk. Da vil de som ikke kan norsk slite mest. De får ikke med seg informasjonen»

\section{Innvandrerrepresentant fra Pakistan.}

Legene gav uttrykk for at mangel på felles språk skapte vansker ved kartlegging av situasjonen og behovet. Både fastlegene og innvandrerrepresentanter informerte om at tolketjenester i liten grad ble etterspurt og brukt. Legene mente at spesielt nyankomne innvandrere fra land utenfor Europa og USA som oftest hadde svake norsk- eller engelskkunnskaper, ikke ønsket å bruke offisielle tolketjenester. Her var fastlegene bekymret for at kommunikasjonsproblemene kunne resultere i misforståelser og feilbehandlinger uten at det finnes et estimat av omfang og konsekvenser. Også innvandrerrepresentanter gav uttrykk for at pasienter kan ha blitt skadelidende på grunn av kommunikasjonsproblemer.

Dette ble opplevd som særlig problematisk i forbindelse med pasienter som har psykiske lidelser eller andre tabubelagte sykdommer. Manglende bruk av tolk begrunnes med at familie og venner foretrekkes, at det er for kort frist før konsultasjonen til at tolk kunne bestilles, at tolketjenesten er nedprioritert på grunn av manglende ressurser eller at 
pasienten ikke ønsker å bruke en tolk fra "samme miljø". Med dette forstås at pasientene ikke føler seg trygge på at tolker fra eget miljø vil ivareta taushetsplikten. I tilfeller der ansatte ved legekontoret ble bedt om å fungere som tolk vil dette kunne medføre at det oppstår en rollekonflikt.

Sammenfattet problematiserer fastlegene adferd fra "ikke-vestlige innvandrere" og beskriver pasientene som rådville. Det er noe legene selv tilskrev språkproblemer og en uavklart forventning til legens rolle og manglende kunnskap om primærhelsetjenesten og fastlegeordningen. Det kom frem at disse tilbakemeldingene fra fastlegene er kjent hos Arbeids- og velferdsforvaltningen (NAV) og at disse barrierene tidligere har blitt tematisert i ulike fora, - uten at det har ført til endringer.

\section{Kvantitative data}

Resultatene fra innvandrerrepresentantene bekreftet både legenes og litteraturens formodninger om at kunnskap om, og kjennskap til, fastlegeordningen er avhengig av følgende:

a) Innvandrernes bolengde i Norge.

b) Mottatt og oppfattet informasjon om helsesystem generelt og fastlegeordningen spesielt.

c) En for begge tilfredsstillende pasient-legekommunikasjon og interaksjon.

d) Innvandrerens landbakgrunn.

e) Årsaken til migrasjonen.

f) Helse-, lese- og språkkunnskaper.

Disse resultater ble lagt til grunn for å kunne se nærmere på sannsynligheten for å bruke legevakt fremfor fastlege, estimering av omfanget av dette og tolking av de ulike funnene.

Derfor belyser den kvantitative delen (beskrevet i Goth og Godager, 2011) omfang og demografiske variabler som fødeland, bolengde og kjønn ved ulike innvandrere i Oslo og hvor sannsynlig det er om de velger legevakten fremfor fastlegen.

Datamateriale som belyser problemstillingen i den kvantitative delen baserer seg på data fra konsultasjonsdatabasen, som ble analysert i henhold til nasjonal bakgrunn, alder, kjønn og forholdet mellom primærlege og legevaktkonsultasjon. 
Tabell 1:

Demografisk oversikt over bruk av legevakten og fastlege i Oslo for årene 2006-07.

\begin{tabular}{|l|l|l|l|l|l|}
\hline & Antall & $\begin{array}{l}\text { Alder } \\
\text { (gj.snitt) }\end{array}$ & $\begin{array}{l}\text { Kvinne } \\
\text { r(\%) }\end{array}$ & $\begin{array}{l}\text { Fastlege } \\
\text { besøk } \\
\text { (pr.år) }\end{array}$ & $\begin{array}{l}\text { Legevakts } \\
\text { besøk } \\
\text { (pr. år) }\end{array}$ \\
\hline $\begin{array}{l}\text { Norske } \\
\text { foreldre }\end{array}$ & $\begin{array}{l}222.119 \\
(79,5)\end{array}$ & 48,5 & 57,0 & 4,2 & 6,6 \\
\hline $\begin{array}{l}\text { Innvandrere } \\
\text { (1.gen.) }\end{array}$ & $\begin{array}{l}53.499 \\
(19,1)\end{array}$ & 40,8 & 54,2 & 4,7 & 7,7 \\
\hline
\end{tabular}

Tabell 1 (over) gir en samlet oversikt over antall konsultasjoner ved legevakten i Oslo og fastlegene for personer som er folkeregistret i Oslo.

I 2007 ble det registrert tilnærmet 100.000 innvandrere i Oslo (Statistisk sentralbyrå, tabell 05182) hvorav 50.136 var menn og 48343 var kvinner). Som tabell 1 viser står innvandrere for $19,1 \%$ av legevaktkonsultasjonene, noe som viser at innvandrere oftere enn etniske nordmenn foretrakk konsultasjoner ved legevakten fremfor å benytte fastlegen. Justert for alder, kjønn, botid og fødeland i logistisk regresjon hadde innvandrere $20 \%$ større sannsynlighet for å velge legevakten ved behov for primærlege enn etniske nordmenn (tall ikke vist i tabellen). Bruken av legevakt var høyest for barn og for dem over 65 år, og er uavhengig av kjønn. Innvandrerne har ulike utgangspunkt, ulike behov og kommer fra ulike land. Med tanke på dette ble konsultasjonsvalget belyst i forhold til de fødeland som er registrert i folkeregisteret. Resultat av regresjonsanalysen vises i Tabell 2. 
Tabell 2:

Innvandrergruppene bosatt i Oslo og deres bruk av legevakt, fastlege i årene 2006 og 2007 i hht. fødeland, botid, kjønn og alder.

\begin{tabular}{|c|c|c|c|c|c|c|}
\hline Fødeland & Antall & Alder & Kvinner & Botid & $\begin{array}{l}\text { Primærlegeb } \\
\text { esøk }\end{array}$ & Legevaktsbesøk \\
\hline & Gj.snitt & & Gj.snitt & $\begin{array}{l}\text { Antall } \\
\text { per år }\end{array}$ & & \\
\hline Norge (fra Tabell 1) & 222119 & 48.5 & 57 & & 4.2 & 6.6 \\
\hline Sverige & 3958 & 38.2 & 59.7 & 10 & 3.6 & 8.9 \\
\hline Danmark & 1675 & 50.6 & 55.8 & 21.6 & 4 & 6 \\
\hline Polen & 1458 & 41 & 57.6 & 11 & 3.9 & 10 \\
\hline Irak & 1920 & 34.2 & 44.6 & 7.6 & 5.5 & 8.9 \\
\hline Tyskland & 1013 & 45.9 & 59.2 & 15.7 & 3.8 & 5.3 \\
\hline Bosnia & 1205 & 42.6 & 53.7 & 12.5 & 4.7 & 7.8 \\
\hline Somalia & 2660 & 34.8 & 52.8 & 8.9 & 5 & 11.7 \\
\hline Pakistan & 6113 & 39.6 & 51.3 & 16.6 & 5.7 & 7 \\
\hline Vietnam & 1903 & 40.1 & 58.6 & 16.6 & 4.3 & 5.3 \\
\hline Russland & 746 & 37.2 & 78.4 & 7 & 4.2 & 6 \\
\hline Iran & 2323 & 39.7 & 49.2 & 13 & 5.2 & 7.2 \\
\hline Storbritannia & 937 & 48.1 & 40.9 & 18.1 & 3.7 & 6.1 \\
\hline Tyrkia & 1838 & 37.7 & 48.7 & 14 & 5.4 & 8 \\
\hline Sri Lanka & 2878 & 39.1 & 51.6 & 13.2 & 5.2 & 8 \\
\hline Andre & 21144 & 40.5 & 55 & 13.1 & 4.4 & 7.6 \\
\hline
\end{tabular}

Som tabell 2 viser hadde innvandrere født i Tyskland, Vietnam, Russland, Danmark og Storbritannia mindre bruk av både legevakt og fastlege enn etniske nordmenn. Innvandrere fra de resterende landene som er inkludert i analysen, kontaktet legevakten oftere enn etniske nordmenn. Innvandrere fra Polen representerer her et unntak. Disse hadde få fastlegebesøk og den nest høyeste andelen besøk på legevakten. Somalierne hadde høyest andel legevaktbesøk. 
For å kunne visualisere effekten av botid benyttet vi variablene (botid, innflytningsdato, kjønn, alder, fødeland) som utgangspunkt til å estimere forventet kontakt av legevakt i stedet for fastlege. For fremstillingen ble det tatt utgangspunkt i en gjennomsnittsperson en kvinne i alder 45. Dette utgangspunktet ble valgt da de fleste kvinner i denne alderen ikke har situasjonsbetinget legekonsultasjoner som graviditet og menopausen (eks. urinveisinfeksjoner eller andre somatiske plager). Valg av kvinne fremfor mann begrunnes med stabil og sammenlignbar ulykkesstatistikk, som i mindre grad omfatter situasjoner der fastlegen ikke er et reelt alternativ.

Figure1:

Estimert betydning av botid på sannsynligheten for et legevaktsbesøk for en 45 år gammel kvinne med to primærhelsetjenestebesøk per år etter utvalgte fødeland

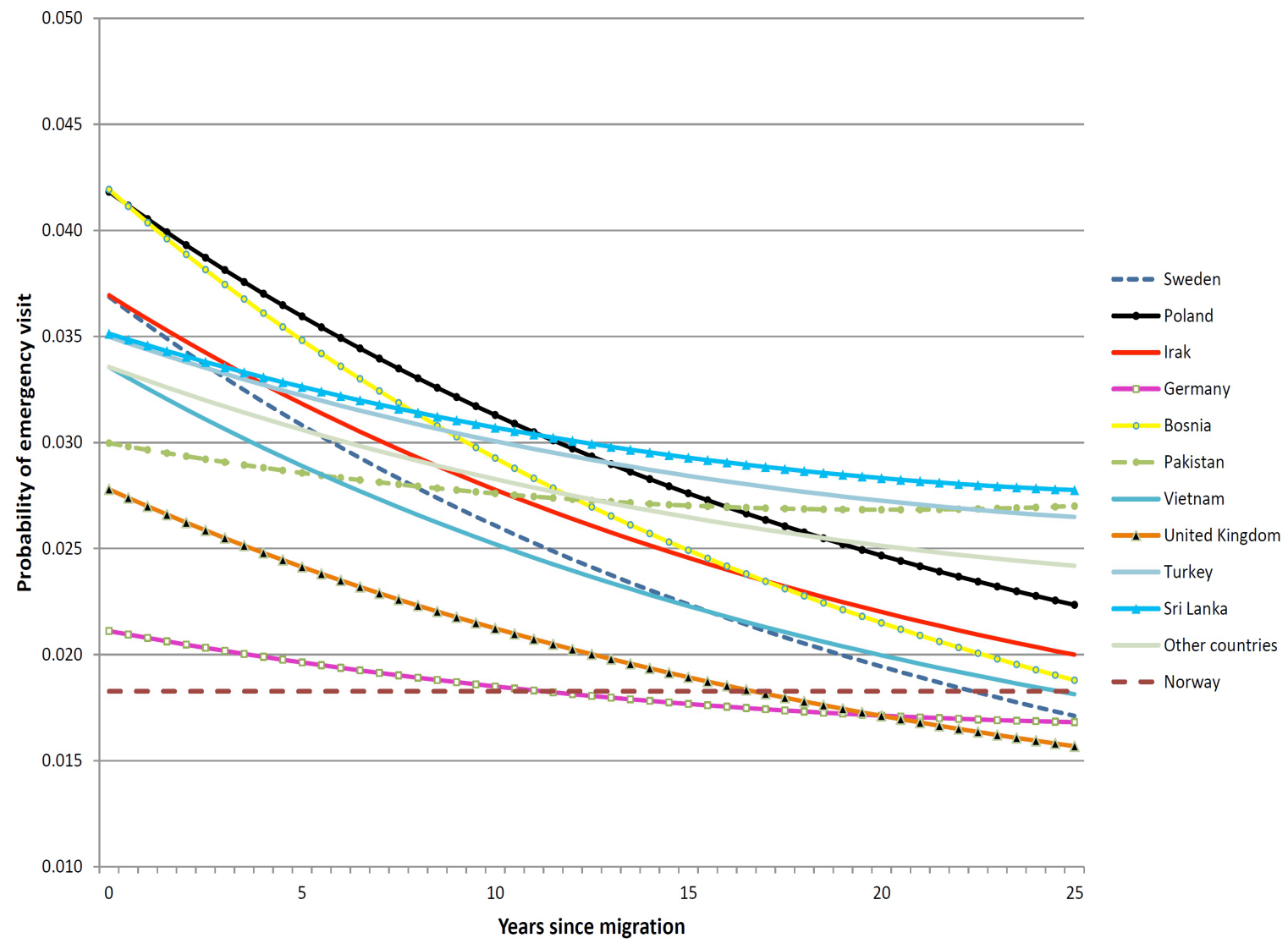

Referanse: Use of primary care emergency services in Norway: impact of birth country and duration of residence (Goth \& Godager, 2013).

Figur 1 viser på $y$-aksen sannsynligheten for å bruke legevakt fremfor fastlegen og på xaksen indikerer botid - altså år siden bosetting i Norge. Personer som er født i Norge, og som dermed ikke har flyttet hit, vises som rett linje. Som figur 1 viser faller tendensen til a søke legevakten med økende botid i Norge. Dette viste seg å være tilfelle for alle innvandrergrupper som ble inkluderte i studien. Det som er interessant er at kurvene som representerer innvandrere fra ulike land viser et så mangfoldig og signifikant mønster. Noen grupper innvandrere hadde sterkt fall i sannsynligheten for å bruke legevakt fremfor 
fastlege i løpet av 25 års botid. Dette gjaldt personer født i Polen, Bosnia, Vietnam, Irak, Sverige og i noe mindre grad Storbritannia. Derimot viste analysen at personer født i Sri Lanka, Tyrkia og Pakistan hadde en tendens til å velge legevakten frem for fastlegen selv etter lenger botid. Disse hadde mindre sannsynlighet for å bruke legevakten i forhold til de andre gruppene de første årene og endte opp med et lik eller høyere sannsynlighet for bruk i forhold til de andre gruppene over tid. Innvandrere fra Tyskland derimot hadde allerede ved innflytningsdato liten sannsynlighet for å bruke legevakt frem for fastlegen - og dette reduserte seg til under "majoritetsbefolkningens" gjennomsnitt allerede etter 10 àr. Innvandrere fra Sri Lanka, Tyrkia og Pakistan derimot bruker legevakten forholdsvis mye, også etter lang botid.

\section{Diskusjon}

Innvandrernes tilgang kan begrenses av både formelle og uformelle barrierer. De formelle barrierene omfatter organisasjonsrelaterte hindringer (Brome, Dalstedt og Schølin, 2007), og manglende informasjon om eksisterende og tilrettelagte tilbud (Burns, Imrie og Nazroo, 2007). Helsetjenestens uformelle barrierer sees her som et komplekst problem skapt av manglende språkkunnskap, manglende kommunikasjon, sosiokulturelle faktorer (Bhopal, 2007; Goth og Berg, 2011) samt det å være "ny" i landet. Den enkeltes oppfatninger av sykdom og helsemessige risikofaktorer kan variere i forhold til kultur og religion $(\mathrm{Hjelm}$, Bard, Nyberg et al, 2005). Dette kan igjen være koblet til visse forventninger og holdninger som kan innvirke på forholdet mellom pasienten og legen og påvirke helsevesenets funksjon som sådan (Dyhr og Krasnik, 2006).

Tilnærmingene som Berry (1992) betegnet som "culture shedding" er en "avlæring" av aspekter og tidligere lærte adferdsmønstre som ikke lenger er aktuelle. $\AA$ ikke beherske det som forventes kan oppleves som forvirrende og nedverdigende. I møte med nyankomne innvandrerpasienter er det derfor avgjørende å vise toleranse og forståelse for innvandrernes egne perspektiv og forventninger. Utgangspunktet er at innvandrere som visuelt skiller seg ut fra majoritetsbefolkningen opplever mer fordommer og har et mer divergerende adferdsmønster (Berry et al. 1989). Sammenhengen mellom kulturell kontekst og individuell adferd (Berry, 1997/1992) kan forklare flere av de mulige årsakene til at innvandrere foretrakk å oppsøke legevakt. Disse var:

1) at de manglet informasjon om norsk primærhelsetjeneste,

2) hva som i gitte situasjoner fremstår som akseptabelt ut fra egne normer og verdier,

3) eller at legevakten i opprinnelsesland fungerer på en annen måte enn i Norge.

Samtlige av de intervjuede legene etterlyste informasjon om fastlegeordningen formidlet på innvandrerens morsmål. Slik informasjon burde også inkludere en avklaring om rolleforventningene. Utforming av tjenestetilbudene i primærhelsetjenesten bør skje i samarbeid med brukerne, herunder også innvandrerne. Dette er nødvendig i et samfunn der mennesker møter et mangfold av tankemønstre, verdinormer, kommunikasjonsmåter og forhandlingsstiler (Yousefi, 2006).

Holdninger og tidligere lærte adferd vedlikeholdes, noe som kan tyde på at akkulturasjon ikke oppnås (Ward, 2013). Dette kan vise seg i situasjoner med uavklarte rolleforventninger eller være forårsaket av tidligere erfaringer med helsesystemet. Disse ulike årsakene viste seg à være begrunnelsen for innvandrernes legevalg. Lignende funn gjort av Haugen (2010) og Djuve, Sandbæck og Lunde (2011) bekrefter at et negativt syn på helsetjenester kan skyldes dårlige erfaringer og problemer med kommunikasjonen. 
Språket er ikke bare grunnleggende for å beskrive egne helseproblemer, men også avgjørende for evnen til å gjøre avtaler (Nielsen, 2006). En norsk studie som belyste situasjonen hos fastlegen, viste at åtte av ti fastleger til stadighet ikke bruker profesjonelle tolker (Smedtorp, 2008). Dersom den enkeltes språkkunnskaper ikke strekker til, kan en offentlig oversetter eller tolk brukes. Men dersom det ikke brukes trente og skolerte oversettere risikerer man at kommunikasjonen blir skadelidende, noe som kan medføre feilbehandling (Aftenposten, 2011). Dette kan ikke bare føre til vansker med à formidle informasjon, men også vansker med å identifisere aktuelle helseproblemer (Higgins og 0 'Donnell, 2007), noe som igjen kan få alvorlige konsekvenser for pasienten. Mens legevakten i store byer tilbyr et lavterskeltilbud hele døgnet alle dager, så kan fastlegen med timeavtale og ventetid oppfattes som vanskeligere tilgjengelig. Det viste seg at særlig de nyankomne innvandrerne med språklige utfordringer har erfart at legekonsultasjon ikke oppnås innen ønsket tidsramme eller er lite tilfredsstillende. Derfor velger de à bruke legevakten fremfor fastlegen (Goth, 2012).

Men disse språklige utfordringene oppleves ikke bare under selve legebesøket. Som regel ble heller ikke introduksjonsbrevet med informasjon om fastlegeordningen forstått. Som nevnt i resultatavsnittet distribuerer HELFO informasjonen om tildelt fastlege og om selve fastlegeordningen seks uker etter at innvandreren har kommet til Norge. Informasjonen distribueres bare på norsk (bokmål eller nynorsk), og det er mer enn tvilsomt at innvandrere etter bare seks uker i landet har tilegnet seg tilstrekkelige norskkunnskaper til å kunne forstå et standardisert informasjonsbrev, som i tillegg forutsetter et betydelig ordforråd. Initialbrevet fra HELFO sendes til den adressen som er registrert hos Folkeregisteret. Denne registreringen skjer som regel umiddelbart etter ankomsten til Norge, og følgelig på et tidspunkt da mange ennå bare har en midlertidig adresse. Initialbrevet kommer ofte ikke frem til den adressen vedkommende senere oppholder seg på. I dag, 10 år etter introduksjon av Fastlegeordningen, er det nesten uten unntak innvandrere som mottar slike informasjonsbrev i posten.

Det er en nær sammenheng mellom språk og meningsunivers. Som kommunikasjonsverktøy må språk derfor kombineres med en kultursensitiv tilnærming for å kunne fremme eller formidle kunnskap og forståelse. Likevel er det ikke mulig for den enkelte til å forstå alle de ulike meningsuniversene en møter. Kultursensitivitet beskriver derfor en tilnærmingsmåte der en gjennom å kjenne til eksistensen av ulike meningsunivers samtidig åpner for en søkende tilnærming til betydningen av andres ytringer og handlinger uten at en har detaljert forhåndskunnskap om disse. Dette oppnås gjennom bevisst à utvide den individuelle forståelsesrammen (Magelssen, 2008,Foronda, 2008).

Det statistisk påviste mønsteret av endring i bruken av primærhelsetjenester i forhold til botid, og mellom ulike innvandrergrupper, kan ha flere forklaringer. Én av årsakene kan være at tilpasningen viser til endringer som finner sted i respons til samfunnsmessige krav (Berry, 1997). En annen forklaring kan være knyttet til årsaken til at personen innvandret. For eksempel vil polsk- og svenskfødte personer være arbeidsinnvandrere, trolig med god helse. Dersom disse oppsøker legevakten er sannsynligheten stor at det er på grunn av et reelt eller opplevd behov for øyeblikkelig hjelp. Som det kommer frem av intervjuene besøkes fastlegen når innvandreren er på besøk "hjemme" i Polen eller Sverige. Derimot har personer som er født i Danmark ofte bodd lengre i Norge enn svensker og polakker og har derfor mest sannsynlig tilegnet seg et "norsk" bruksmønster (tabell 2).

Kulturelle forskjeller kan gi ulike utgangspunkt for å lære det norske helsevesenet å kjenne. Grupper som etter lengre botid i Norge fortsetter à velge legevakten fremfor fastlegen kan ha utfordringer med à navigere $\mathrm{i}$ det norske helsesystemet. Her nevnes det spesielt personer med flyktningebakgrunn fra Sri Lanka. Innvandrere med bakgrunn fra Vietnam 
utgjør her et interessant unntak. Arbeidsinnvandrere fra Pakistan endrer i minst utstrekning sine preferanser for legevaktstjenester.

Andre undersøkelser viser at helsetilbudenes tilgjengelighet også kan være avhengig av førstelinjepersonalet, som for eksempel sykepleiere og kontorpersonale som pasientene møter ved initialkontakten (Negaard, 2008).

Kontinuitet og stabilitet i forholdet mellom fastlege og pasient er en nøkkelfaktor i norsk helsepolitikk for å sikre kvaliteten i tjenestene (Helse- og omsorgsdepartementet, 2006). For å oppnå dette er det nødvendig at alle innbyggerne har en likeverdig tilgang til sin fastlege. En sentral utfordring for systemet består i at det økende mangfoldet i befolkningen også medfører et økende behov for tilrettelagt informasjon. Våre resultater tyder på at nyankomne innvandrere er en gruppe som i særlig grad faller utenfor den etablerte informasjonspraksisen om fastlegeordningen.

Det norske utvalget $\mathrm{i}$ en europeisk studie viser at den foretrukne legekonsultasjonen blant annet kan gjenspeile pasientens sosiale struktur, da denne varierer i forhold til utdanning og hva som i gitte situasjoner fremstår som akseptabelt ut fra normer og verdier (KlüwerTrotter og Lian, 2012). Flere leger påpekte at det ofte tok lengre tid å innfri enkelte av de medfølgende pårørende sine forventninger enn pasientens egne. Lignende funn ble også gjort av Goth, Netskar og Misvær i 2012.

Den sosiale kapitalen som nyankomne utvikler og de kontakter den enkelt knytter etter ankomst, er hovedsakelig innen eget innvandrermiljø (Faist, 1977). Derfor står innvandrerorganisasjonene her sentralt gjennom å tilby lavterskel samlingspunkt med utgangspunkt $\mathrm{i}$ kjente og gruppespesifikke interesser, høytider og sosiale organiseringer.

Interaksjon med "den andre" basert på forståelse av beveggrunner ble beskrevet som kultursensitivitet. Dette uttrykker en bevissthet om at det finnes andre forståingsmåter, underforstått at toleranse viser til at man kan, men ikke må, være enig i "den andres" synspunkt. I stedet vil innsikten i at all meningsdanning skje på bakgrunn av egne og/eller gruppespesifikke erfaringer, gi grunnlag for kommunikasjon gjennom å overskride egne forståelsesrammer.

\section{SENTRALE FUNN OG ANBEFALINGER}

Resultatene som omhandlet utilsiktede problemer og mønstrene $\mathrm{i}$ fastlegeordningen viste store forskjeller mellom innvandrergruppene og understreker betydningen av dialog med både innvandrergruppene og deres representanter.

Med utgangspunkt i de påviste forhold følger her en punktvis oppsummering av hvordan utfordringene knyttet til innvandreres bruk av fastlegeordningen kan løses:

1. All informasjon om fastlegeordningen og tildeling av lege bør språklig og innholdsmessig tilpasses de aktuelle gruppene. Informasjonskanalene kan være ulike mellom innvandrergruppene og enkeltpersoner. Det bør benyttes kanaler som når minoritetsgruppene. Eksempler på slike grupper er religiøse foreninger, innvandrerorganisasjoner, Rådet for innvandrere, avisen Klar Tale og TV-programmet Migrapolis.

2. Det bør innføres rutiner som sikrer at fastlegen mottar epikrise etter pasientenes besøk på legevakten. 
3. Det bør vurderes om et vederlagsfritt initialbesøk hos fastlegen kan fremme kjennskap til systemet og den ønskede stabiliteten i pasient-legerelasjonen. Pasienter som ikke har benyttet seg av tildelt lege bør informeres på nytt.

4. Legevaktene i byene kan være et mulig sted å nå frem med informasjon om helsesystemet og rolleforventninger. Det er her nyankomne innvandrere henvender seg i situasjoner med påtrengende nødvendig helsehjelp, og dersom informasjonen om fastlegen ikke er blitt mottatt eller forstått. Legevaktene i storbyene har også mulighet à oppdage eventuelle uregistrerte adresseendringer.

\section{Hovedbudskap}

Innvandrere bruker legevakten i større utstrekning enn norskfødte

- Informasjon om primærlegetjenesten når ofte ikke frem til nyankomne innvandrere

$\rightarrow$ Informasjon om fastlegeordning og helsetjenester bør gis ved ankomst til Norge og på innvandrernes morsmål

$\downarrow$ Det bør opprettes et samarbeid med innvandrerorganisasjonene for å formidle slik informasjon 


\section{Referanser}

Berry, J. W., Kim, U., Power, S., Young, M. \& Bujaki, M. (1989). Acculturation attitude in plural societies. Applied Psychology Review. (38):185-206.

Berry, J. W. (1992). Acculturation and adaption in a new society. International Migration. (30):69-85.

Berry, J. W. (1997). Immigration, Acculturation, and Adaption. Applied Psychology Review. 46(1):5-34.

Berry, John W., Poortinga, Y.H., Breugelmans, S.M., Chasiotis, A. \& Sam D.L. (2011). Cross-Cultural Psychology. Research and Applications. (3). Cambridge: Cambridge University Press.

Bhopal, R. S. (2007). Ethnicity, race and health in multicultural societies: Foundations for better epidemiology, public health, and health care. New York, Oxford University Press

Blom, S. (2010). Holdninger til innvandring. Oslo, Statistisk sentralbyrå.

Bøhn, H. (2008). Acculturation and Identity in Adolescents in Norway. Journal of Intercultural Communication. Online 2008. Brome, P, Dalstedt, I, Schølin, T. (2007). Indicators of Diversity: Content or Packaging? Malmø, IMER Research. Lest 3.juli 2012 fra: http://dspace.mah.se/dspace/bitstream/handle/2043/3993/Current\%20themes

Burns, F. M, Imrie, J. Y, Nazroo, J, et al. (2007). Why the(y) wait? Key informant understandings of factors contributing to late presentation and poor utilization of HIV health and social care services by African migrants in Britain. AIDS Care. (19):102108.

Dahl, Ø. (2013). Møter mellom mennesker: ínterkulturell kommunikasjon. Oslo, Gyldendal akademisk .

Djuve, AB, Sandbæk, ML \& Lunde, H.(2011). Likeverdige tjenester? Storbyens tjenestetilbud til en etnisk mangfoldig befolkning. Fafo-rapport 35 .

Dyhr, L, Krasnik, A. (2006). International migration og sundhet: En utfordring til forskning og sundhedspolitik i Danmark! Ugeskrift for Læger. (168):2651-3.

Faist, T.(1997). Migration und der Transfer sozialen Kapitals oder: Warum gibt es relativ wenige internationale Migranten? Soziale Welt (12)

Foronda, Cl. (2008). A Concept Analysis of Cultural Sensitivity. Journal of Transcultural Nursing. (19):207 (online).

Glaser, BG, Strauss, AL. (1967).The Discovery of Grounded Theory. Strategies for Qualitative Research, Chicago, Aldine.

Godager, G, Iversen, T. (2010). Brukernes erfaringer med fastlegeordningen 2001-2008: trender i bruk, tilgjengelighet og fornøydhet. Oslo, Helseøkonomisk forskningsprogram ved Universitetet i Oslo.

Goth, U. G. S, Berg, J. E, Akman, H. (2010). The intercultural challenges of general practitioners' in Norway with migrant patients. International Journal of Migration Health and Social Care 2010. (6):26-33.

Goth, U. G. S, Berg, J. E. (2011). Migrant participation in Norwegian health care: A qualitative study using key informants. European Journal of General Practice. (17):2833.

Goth, U.G. S, Godager, G. (2012). Use of primary care emergency services in Norway: impact of birth country and duration of residence. Nordic Journal of Health Economics . Online publication;.

Goth, U.S.(2012). Immigrants use of the General Practitioner Scheme- a Mixed Method study analyzing access of Primary Health Care service in acute but not life-threatening medical situations. Oslo, Reprosentralen: Universitetet i Oslo. 
Goth, U.S, Netskar, A. K, Misvær, N. (2012). Forebygging av uønsket svangerskap og abort blant ikke-vestlige innvandrere. Tidsskrift for jordmødre. (8):24-29.

Halvorsen, I, Meland, E, Bærheim, A. (2007). Bruk av legevakt før og etter fastlegeordningen. Tidsskrift for den Norske Legeforening. (127):15-7.

Haugen, T. B. Etniske minoriteters syn på helsetjenester. (2010). Tidsskrift for den Norske Legeforening.(130):245. Doi: 10.4040/tidsskr.10.0039.

Helse- og omsorgsdepartementet.(2006). Nasjonal helseplan for Norge (2007-2010). Lest 10.6. $2013 \mathrm{fra} \mathrm{http://www.regjeringen.no/Upload/HOD/Vedlegg/Engelsk/}$

Higgins, M, O 'Donnell, C.A.(2007). Involving refugees in focus group research: In Williamson A and De Souza R. (eds) Researching within Communities: Grounded Perspectives on Engaging Communities in Research. Aukland, New Zealand, Muddycreek Press, :167-179.

Hjelm, K., Bard, K., Nyberg, P. \& Apelqvist, J. (2003). Religious and cultural distance in beliefs about health and illness in women with diabetes mellitus of different origin living in Sweden. International Journal of Nursing Studies. 40(6) 627-643.

Hjelm, K.G, Bard, K, Nyberg, J et al.(2005). Beliefs about health and diabetes in men of different ethnic origin. Journal of Advanced Nursing. (50):47-59.

Ihle, R.(2008).Søkelys: perspektiver på arbeid med etniske minoriteter $i$ velferdstjenestene. Kristiansand, Høyskoleforlaget. 3.

Johnsen, B. H. (1986 ). Innenfra-perspektivet: en metodisk utfordring i kvinnehistorie. Dugnad 2(3):47-72.

Klüwer-Trotter, B, Lian, O. S.(2012). Holdninger til legesøkning-variasjoner etter sosial tilhørighet? Tidsskift for Norsk Legeforening.(132):36-40.

Kymlicka, W.(1995). Multicultual citizenship. Oxford, Clarendon Press.

Magelssen, R.(2008). Kultursensitivitet-om \& finne likhetene $i$ forskjellene. Oslo, Akribe

Negaard, TB.(2008).Eldres bruk av pleie og omsorgstjenester: rapport fra fem storbykommuner. Oslo, Norsk institutt for forskning om oppvekst, velferd og aldring. 2008/79.

Nielsen, AS.(2006). Smertelige erfaringer. En antropologisk analyse af migrantkvinders fortællinger om sykdom, marginalisering og diskursiv hegemoni. PhD avhandling, Institut for Folksundhedsvidenskab. Københavns Universitet.

Patton, MQ. (2002). Qualitative Research and Evaluation Methods, 3d Edition. Thousand Oaks, CA: Sage Publications.

Redfield, R., Linton, R., \& Herskovits, M.J. (1936). Memorandum for the study of acculturation. American Anthropologist, (38):149-152.

Skirbekk S. (1975) Akkulturation i Oslo: En studie av by og bygdekultur (SkriftserieInstituttet for sosiologi, Universitetet i Oslo: nr. 26.

Smedtorp, IC.(2008). Fastleger og tolkebruk. Master thesis. Samfunnsmedisin. University of Oslo.

Statistisk Sentralbyrå (2013). Immigrants and Norwegian-born to immigrant parents, 1st January 2013. (sist lest 21.10.2013:

http://www.ssb.no/en/befolkning/statistikker/innvbef).

Statistisk Sentralbyrå (tabell 05182). Befolkningsstatistikk: Befolkningsendringer i kommunene 1951-2011: 0302 Oslo:SSB Folkemengde 1. Januar og endringer i året. Oslo: SSB. online (sist lest 30.10.2013: http://www.ssb.no/tabell/05182)

Statistisk Sentralbyrå. Metadata. Definisjon. (sist lest 23.01.2014: http://www4.ssb.no/stabas/ItemsFrames.asp?ID =5538057\&Language =nb)

Stortingsmelding 10 God kvalitet - trygge tjenester. Sist lest 15.10.2013. http://www.regjeringen.no/nb/dep/hod/dok/regpubl/stmeld/2012-2013/ 
Teddlie, C, Tashakkori, A.(2009). Foundations of Mixed Methods Research. Sted? Sage Publications.

Vassenden, K. (2012). Hvor stor er egentlig innvandringen. Samfunnspeilet 2012/3. Oslo: Statistisk sentralbyrå.

Ward, C. (2013). Probing identity, integration and adaption: Big questions, little answers. International Journal of Intercultural Relations.37(4):391-404.

Yousefi Reza, H.(2006). Angewandte Toleranz: Interkulturelle Bibliothek. Band 49 Verlag Traugott Bautz GmbH: Nordhausen. 